\title{
Change in glacier area and thickness in the Tomur Peak, western Chinese Tien Shan over the past four decades
}

\author{
Huai Baojuan ${ }^{1,2, *}$, Li Zhongqin ${ }^{1,3}$, Sun Meiping ${ }^{3}$, Wang Wenbin ${ }^{1}$, Jin Shang ${ }^{1}$ and Li Kaiming ${ }^{4}$ \\ ${ }^{1}$ State Key Laboratory of Cryosphere Science, Cold and Arid Region Environment and Engineering Research \\ Institute, Chinese Academy of Sciences (CAS), Lanzhou 730000, China. \\ ${ }^{2}$ University of Chinese Academy of Sciences, Beijing 100049, China. \\ ${ }^{3}$ Geography and Environment College of Northwest Normal University, Lanzhou 730070, China. \\ ${ }^{4}$ School of Urban Economics and Tourism Culture, Lanzhou City University, Lanzhou 730070, China. \\ *Corresponding author.e-mail: huaibaojuan@126.com
}

This paper looks at glacier area change in the Tomur Peak for the 1964/71-2000 and 2000-2011 periods. The results show that the total area of the selected 78 glaciers has decreased from $555.45 \mathrm{~km}^{2}$ in $1964 / 71$ to $530.39 \mathrm{~km}^{2}$ in 2000 , and further reduced to $521.89 \mathrm{~km}^{2}$ in 2011 . Overall, the selected glaciers have lost $4.50 \%$ of their surface area between $1964 / 71$ and 2000, and have lost $1.60 \%$ more between 2000 and 2011. The area reduction rate of the 78 glaciers increased from $0.12 \%$ /a during 1964/71-2000 to 0.13\%/a during 2000-2011. In addition, this paper describes a method for estimating the ice surface elevation change using the SRTM (2000) and elevation data generated from topographic maps (1964/71) to quantify the ice thickness change for the 1964/71-2000 period. The surface elevation for about $73.50 \%$ of grid area decreased, mostly in the glacier ablation zone. The overall average thickness loss is $22.35 \mathrm{~m}$ which yields an annual loss of $0.60 \mathrm{~m} / \mathrm{a}$.

\section{Introduction}

Mountain glaciers are considered to be a reliable indicator of climate change (Houghton 2001). The interest in worldwide monitoring of glaciers has grown as evidence of rapid glacier recession in many regions of the world is reported. Glacial evolution monitoring essentially consists of tracking the variations in the spatial extent and the changes in mass, thickness, and volume of glaciers (Josberger et al. 1993; Bayer et al. 1994). Remote sensing technologies provide a suitable way to show the spatial distribution of monitored glaciers, especially in remote areas (Frezzotti et al. 1998; Kaab et al. 2003; Bishop 2004; Paul et al. 2004). Spaceborne techniques are actually the only method to ensure sustainable, global-scale monitoring of glaciers. Moreover, space-borne methods have been developed and successfully applied for detecting glacier area changes and glacier movements. The current glacier monitoring from space includes measurements of glacier area change (Josberger et al. 1993; Bayer et al. 1994), glacier thickness change, and volume change (Aðalgeirsdóttir et al. 1998; Berthier et al. 2004; Smith et al. 2005; San and Suzen 2005). The detection of the area change of a glacier requires multi-temporal images, which are very effective owing to their moderate spatial and temporal resolutions. For instance, glaciers in the remote Himalayas can easily be monitored on a seasonal basis with satellite images (Krishna 1996). Thickness or volume changes may be derived from repeated comparison of the surface topography from different years (Sapiano et al. 1998;

Keywords. Area change; thickness change; SRTM DEM; topographic maps; Landsat ETM ${ }^{+}$; Tomur Peak; glacier. 
Berthier et al. 2004; Berthier and Toutin 2008). Surface topography data (Digital Elevation Models) describing the glacier surface geometry can be extracted by applying modern remote sensing methods (Baltsavias et al. 2001) and evaluation of contour lines on topographic maps. Among a variety of remote sensing data sources, the SRTM DEM is commonly used to assess glacier thickness change at large spatial scales. Most remote sensing approaches are based on the 'geodetic' method (Finsterwalder 1954) consisting in comparing two maps or DEMs of the same area established during different years.

Previous studies of glacier change in the Tien Shan Mountains have used various types of remote sensing data and investigated different time periods (Li and Li 2014; Narama et al. 2010). Most of these works focused on glacier terminus change and glacier surface area change (Wang et al. 2013), while glacier thickness change and glacier volume change research are rarely involved. The main goal of this paper is to derive decadal glacier area change, thickness change, and volume change data for the glaciers of the Tomur Peak area.

\section{Study area}

The Tien Shan Mountains are one of the most important glacier resources in China with 15,953 glaciers with a cumulated area of $15416 \mathrm{~km}^{2}$ (Shi 2005). There are 9081 glaciers in the Chinese Tien Shan, with an area of $9235.96 \mathrm{~km}^{2}$ and a volume of $1011.75 \mathrm{~km}^{3}$ according to the Glacier Inventory of China (GIC) (Shi 2005). The Chinese Tien Shan glaciers are mainly distributed in the Halk Osan
Mountains and Khan TengGeli-Tomur region. The Khan TengGeli-Tomur region, located in the western Chinese Tien Shan, is one of the largest modern glaciated areas in China, counting 509 glaciers with a total area of $2746 \mathrm{~km}^{2}$, a volume of $350 \mathrm{~km}^{3}$, and also represents the largest concentration of glaciers in China, ahead of the Qilian Mountains and Mount Everest.

The computation of glacier changes for all glaciers in the Khan TengGeli-Tomur region presents significant difficulties because of snow coverage, clouds in the images, or errors in the original topographic maps. In this study, 78 glaciers with a combined area of $555.45 \mathrm{~km}^{2}$ were investigated, including some heavily debris-covered glaciers (figure 1). As glacier thickness change and volume change research in this region are rarely involved, this work is significant and meaningful.

\section{Data and methods}

\subsection{Data}

Topographic maps from 1964/71 and Landsat $\mathrm{ETM}^{+}$data from 2000 and 2011 were used to assess glacier area changes for the past four decades. Thickness changes were derived from Digital Elevation Models (DEMs) from topographic maps for 1964/71 and Shuttle Radar Topography Mission (SRTM) for 2000.

\subsubsection{Topographic maps}

Topographic maps at scales of 1:50,000 or 1:100,000 were derived from aerial photographs in 1964/71

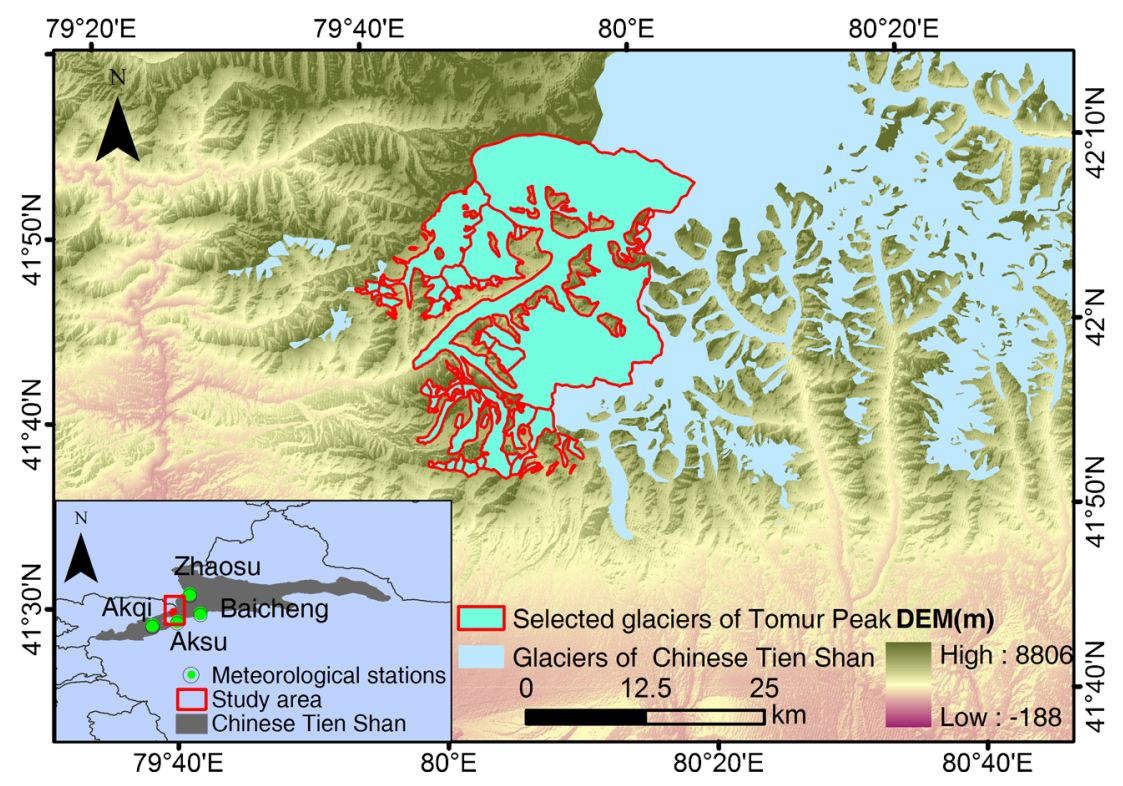

Figure 1. Location of the Tomur Peak glacier. 




Figure 2. (a) Topographic data; (b) SRTM-DEM data; and (c) $20 \mathrm{~m}$ interval contour line data.

(figure 2a). These topographic maps, supplied as a standard product by the Chinese Military Geodetic Service were scanned into digital products. Contour lines were digitized at $20 \mathrm{~m}$ intervals for studying the thickness change (figure 2c). The errors in the $1964 / 71$ contours were reported as 3-5 m over flat and hilly areas and 8-14 m over mountains (State Bureau of Surveying and Mapping 2007). The vertical error of topographic data is between 3 and 4 $\mathrm{m}$; by comparison more than 50 points with SRTM DEM in barren region in the Tomur Peak.

\subsubsection{Remote sensing images}

The main image sources were Landsat $\mathrm{ETM}^{+}$available from USGS (United States Geological Survey, http://glovis.usgs.gov/) and were orthorectified automatically by USGS using the SRTM DEM. The scenes without clouds and little seasonal snow were selected, and they were acquired in 2000 (15, July; path 147, row 31) and 2011 (3, August; path 147, row 31).

\subsubsection{SRTM}

During the Shuttle Radar Topography Mission in February of 2000 , about $80 \%$ of the earth surface elevation data become available. The freely available SRTM DEM (the fourth version) combined with another elevation data at another time point can provide the opportunity to calculate changes in glacier surface elevation. The nominal vertical accuracy is $6 \mathrm{~m}$ relatively and $16 \mathrm{~m}$ absolutely, and the nominal horizontal accuracy is $15 \mathrm{~m}$ relatively and $20 \mathrm{~m}$ absolutely (Rabus et al. 2003). Consistent methodology, coverage, and accuracy of the SRTM data provide a global 'snapshot' of the land surface, and therefore, it could be used as a reference system for local and regional glacier surface elevation change studies (Muskett et al. 2003) as well as for global comparisons. Here we utilized a $90-\mathrm{m}$ resolution SRTM DEM from 2000 and the 1964/71 elevation data from topographic maps to calculate glacier thickness change. The geodetic reference for SRTM data is the World Geodetic System 1984 (WGS84) defined as the 1996 Earth Gravitational Model (EGM 96) geoid (figure 2b).

\subsubsection{Meteorological data}

The annual temperature and precipitation data for the 1960-2011 period is provided by the China Meteorological Data Sharing Service System which is administered by the National Meteorological Information Center (NMIC) of the China Meteorological Administration (CMA). Four meteorological stations were chosen according to the location of the study region, i.e., Zhaosu, Aksu, Baicheng, and Akqi (shown on the inset map of figure 1).

\subsection{Methods}

\subsubsection{Data preprocessing}

Geocorrection and co-registration were conducted using ENVI 5.0 software for all the images. The clearly distinguishable terrain features from topographic maps were used as reference to register the other images. Topographic maps were scanned into digital products at a resolution of $600 \mathrm{dpi}$ and geocorrected to obtain digital raster graphics. All images and maps were presented in a Universal 
Transverse Mercator (UTM) system referenced to the World Geodetic System of 1984 (WGS84).

\subsubsection{Glacier area extraction}

The glacier outlines for the $1964 / 71$ period were extracted from topographic maps using ArcGIS 10. For the 2000 and 2011 periods, a preliminary glacier boundary was automatically generated from the band ratio method. This approach was automatically applied using the band ratio of TM4/TM5 on Landsat images and then complemented with visual interpretation to produce glacier outlines (Bayer et al. 1994; Jacobs et al. 1997; Bolch 2007). Then glacier polygons derived from the ratio method were visually checked for gross errors and were manually improved when necessary (see method overview in figure 3 ).

\subsubsection{Glacier elevation change extraction}

In order to derive the ice thickness change of the Tomur Peak glaciers during the 1964/71-2000 period, the following methods were applied:

- The $1: 50,000$ or 1:100,000 topographic maps were scanned and geocorrected to obtain digital raster graphics, and contour lines of the digital raster graphics were digitized at $20 \mathrm{~m}$ intervals, with the elevation input as the attribute data;

- The SRTM DEM was presented in a Universal Transverse Mercator (UTM) projection and WGS84 reference (Wang and Lu 2003). The widely-used nearest neighbour resampling method was applied to resample the elevation data to a consistent horizontal resolution of $30 \mathrm{~m}$;

- Finally, by subtracting the SRTM DEM from the elevation raster of topographic maps, we were able to compare elevation differences on a cell-by-cell basis.

\subsection{Accuracy assessment}

\subsubsection{Accuracy assessment on area change}

The accuracy of the glacier area change depends on two aspects:

(1) The image resolution and co-registration errors. The spatial resolution of the images $(30 \mathrm{~m})$ and RMSE (Root Mean Square Error) of coregistration affect the measurement accuracy. This uncertainty can be calculated by the following formulae (Hall et al. 2003; Silverio and Jaquet 2005):

$$
\begin{aligned}
& U_{T}=\sqrt{\sum \lambda^{2}}+\sqrt{\sum \varepsilon^{2}} \\
& U_{A}=2 U_{T} \sqrt{\sum \lambda^{2}}+\sqrt{\sum \varepsilon^{2}}
\end{aligned}
$$

where $U_{T}$ is the system uncertainty in the linear dimension; $\lambda$ is the original pixel resolution of image; $\varepsilon$ is the co-registration error of image to the topographic map; and $U_{A}$ is the uncertainty of glacier area;

(2) Glaciers extraction errors affected by debris. The greatest difficulty in mapping glaciers using remote sensing automatic classification is from the presence of debris cover on glaciers. This work used visual aid and manual correction to improve the accuracy. The uncertainty of individual glacier area is calculated as $\pm 0.002 \mathrm{~km}^{2}$.

\subsubsection{Accuracy assessment on thickness change}

The vertical error control is necessary while deriving ice thickness change using multi-source elevation data. There are systematic biases because of geoidellipsoid differences in the mapped elevations. The DEM from the topographic maps are referenced to the 1985 Huanghai elevation system (a meansea level datum), while the SRTM DEM are

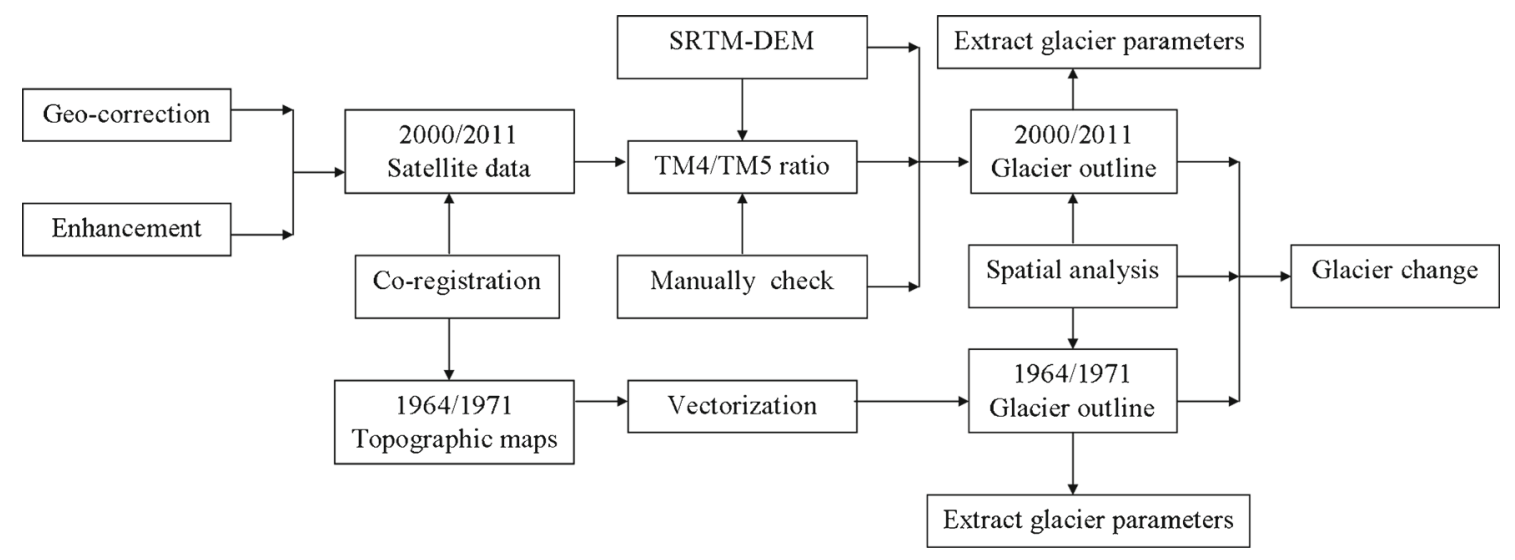

Figure 3. Technical flowchart of glacier outline extraction. 
referenced to the EGM96 vertical datum (geocentric ellipsoidal datum). Guo et al. (2004) concluded that 1985 Huanghai elevation system has an average vertical deviation about $35.7 \mathrm{~cm}$ compared to EGM96 vertical datum and the system deviation increases from east to west. So the SRTM DEM is corrected from EGM96 elevation system to 1985 Huanghai elevation system using following methods:

- We assessed the spatial distribution of vertical errors at the locations where elevation differences between topographic maps and SRTM DEM should be negligible. Subtracting the SRTM DEM from topographic map in selected glacierfree areas, the average difference between the data represented the correction offset. To obtain this elevation offset, it is required to exclude regions where the elevations may have changed due to surface lowering of debris-covered ice or where subaerial erosion of moraines occurred (Arzhan and Aizen 2006; Wang et al. 2010);

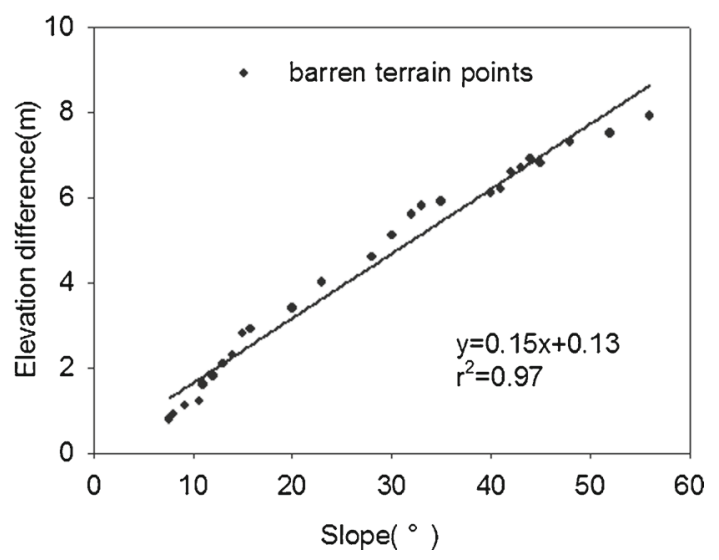

Figure 4. Mean elevation difference between two elevation data sources in different slope ranges over barren terrain sites of the Tomur Peak region.

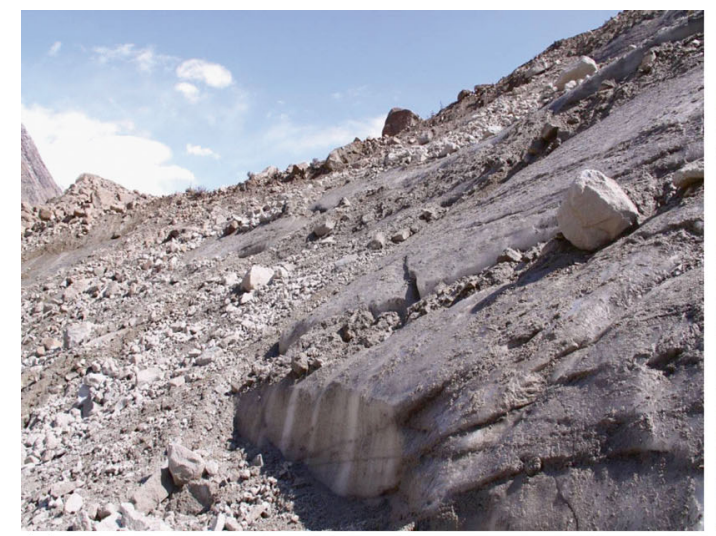

(a)
- We calculated the elevation correction offset for different slope ranges (figure 4) We choose these barren terrain points in every $10^{\circ}$ slope interval. A nearly linear relationship was observed between the elevation difference and slope;

- The correction offset was used to correct glacier thickness change data and different slope ranges were corrected respectively in order to reduce the height anomaly's impact on the altitude.

Furthermore, the terrain of the Tomur Peak region makes it challenging to collect sufficient measured field data. We accomplished a field investigation during 2003 (figure 5).

\section{Results and discussion}

\subsection{Glacier counts and area change}

The topographic map glaciers vector data in $1964 / 71$ and recent glaciers vector data in 2000 and 2011 were carried on with overlay analysis by ArcGIS10 spatial module to obtain glacier changes information (figure 6). According to the statistics of the vector data, the selected number of glaciers in the Tomur Peak decreased from 78 in 1964/71 to 64 by 2000, and it further reduced to 61 by 2011. However, in some regions some large glaciers were divided into several small glaciers correspondingly increasing the counted number of glaciers. So to some extent, the change of glacier count cannot fully reflect the glacier retreat situation. The results show that the total area of the selected 78 glaciers decreased from $555.45 \mathrm{~km}^{2}$ in 1964/71 to $530.39 \mathrm{~km}^{2}$ in 2000 and to $521.89 \mathrm{~km}^{2}$ by 2011 . Overall, the selected glaciers have lost $4.5 \%$ of their surface area from 1964/71 to 2000, and have lost an additional $1.6 \%$ from 2000 to 2011 . The area reduction rate of the 78 glaciers increased from

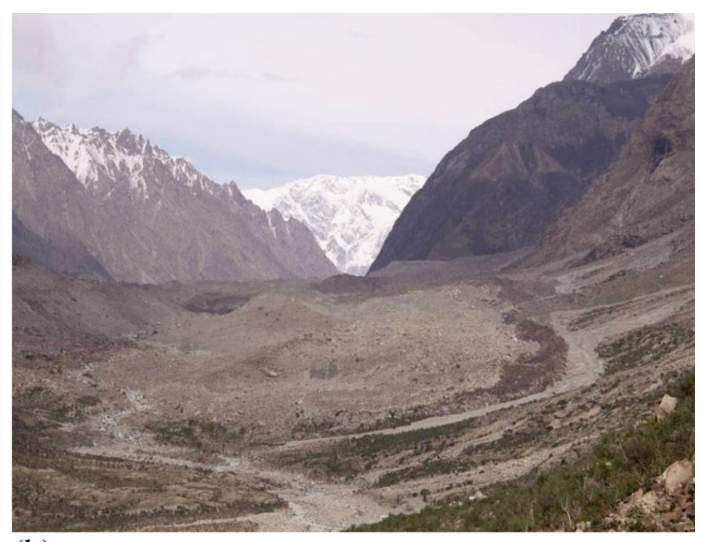

(b)

Figure 5. Field photos in 2003 (Photo taken by Jin). (a) Debris distribution of the Tomur glacier and (b) the terminus position of the Tomur glacier. 


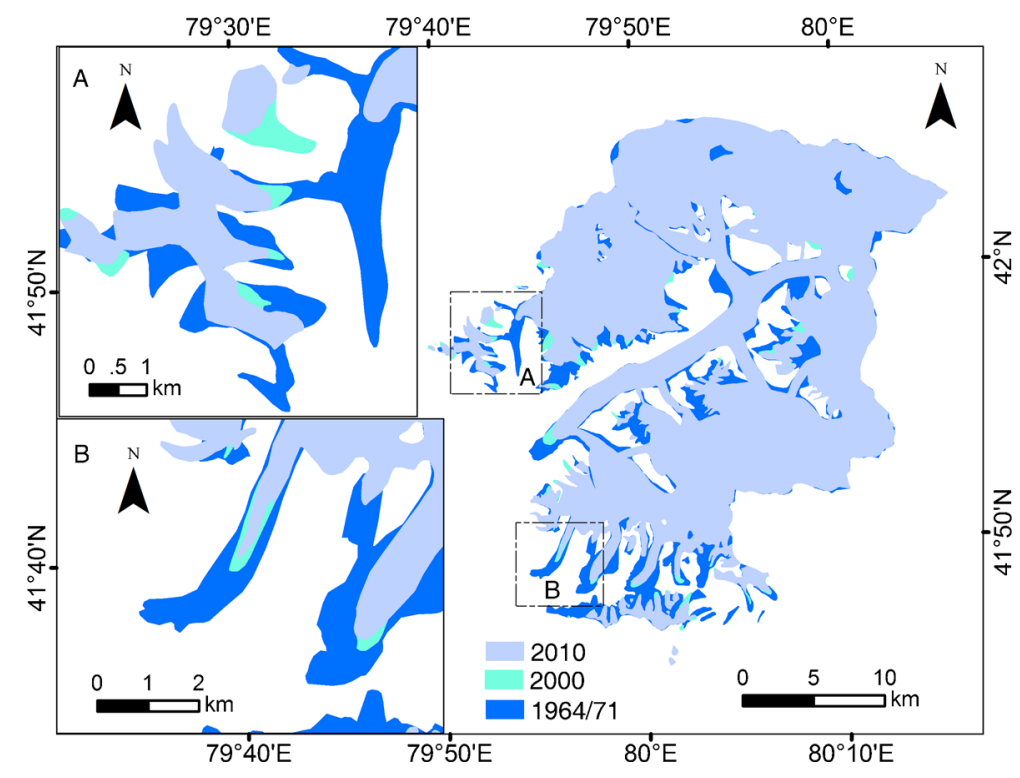

Figure 6. Area change of 1964/71-2000 and 2000-2010 for the Tomur Peak glaciers.

Table 1. The area and length changes of five selected glaciers.

\begin{tabular}{|c|c|c|c|c|c|c|c|c|}
\hline \multirow[b]{3}{*}{ CGI number } & \multicolumn{2}{|c|}{$1964 / 71$} & \multicolumn{2}{|c|}{2000} & \multicolumn{2}{|c|}{2011} & & \\
\hline & \multirow{2}{*}{$\begin{array}{c}\text { Area } \\
\left(\mathrm{km}^{2}\right)\end{array}$} & \multirow{2}{*}{$\begin{array}{c}\text { Length } \\
(\mathrm{km})\end{array}$} & \multirow{2}{*}{$\begin{array}{c}\text { Area } \\
\left(\mathrm{km}^{2}\right)\end{array}$} & \multirow{2}{*}{$\begin{array}{c}\text { Length } \\
(\mathrm{km})\end{array}$} & \multirow{2}{*}{$\begin{array}{c}\text { Area } \\
\left(\mathrm{km}^{2}\right)\end{array}$} & \multirow{2}{*}{$\begin{array}{c}\text { Length } \\
(\mathrm{km})\end{array}$} & \multicolumn{2}{|c|}{ Percentage of area change (\%) } \\
\hline & & & & & & & $\overline{1964 / 71-2000}$ & $2000-2011$ \\
\hline $5 \mathrm{Y} 673 \mathrm{P} 0037$ & 381.26 & 39.50 & 379.56 & 38.80 & 376.70 & 38.40 & -0.45 & -0.75 \\
\hline $5 \mathrm{Y} 673 \mathrm{P} 0072$ & 5.87 & 8.10 & 6.32 & 5.90 & 5.32 & 5.50 & 7.72 & -15.80 \\
\hline $5 \mathrm{Y} 673 \mathrm{P} 0074$ & 11.30 & 9.20 & 8.80 & 7.60 & 8.12 & 7.20 & -22.11 & -7.71 \\
\hline $5 \mathrm{Y} 673 \mathrm{P} 0077$ & 16.16 & 9.90 & 10.30 & 8.30 & 10.00 & 8.10 & -36.26 & -2.52 \\
\hline 5Y673Р0096 & 6.68 & 4.50 & 5.00 & 3.20 & 4.70 & 2.90 & -25.12 & -5.43 \\
\hline
\end{tabular}

$0.12 \% / \mathrm{a}$ in the $1964 / 71-2000$ period to $0.13 \% / \mathrm{a}$ during the 2000-2011 period.

We also selected several glaciers to analyze the glacier changes in detail (table 1). The Tomur glacier $\left(79^{\circ} 50.77^{\prime} \sim 80^{\circ} 7.63^{\prime} \mathrm{E}, 41^{\circ} 48.08^{\prime} \sim 42^{\circ} 2.83^{\prime} \mathrm{N}\right.$; glacier number is $5 \mathrm{Y} 673 \mathrm{P} 0037$ ) is a large valley glacier with an area of $381.26 \mathrm{~km}^{2}$ in 1964/71 and the altitude ranges from 2790 to $7434 \mathrm{~m}$. The glacier area retreated at a rate of $0.05 \mathrm{~km}^{2} / \mathrm{a}$ from $1964 / 71$ to 2000 , and $0.24 \mathrm{~km}^{2} /$ a from 2000 to 2011 , indicating that the retreat of the glacier has been accelerated, based on remote sensing data. Figure 7 shows the terminus positions of the Tomur glacier in 1971, 2000, and 2011. Results show that, the glacier tongue has been observed with a retreat of $718 \mathrm{~m}$ from 1971 to 2000, with an annual retreat rate of $23.9 \mathrm{~m} / \mathrm{a}$; and the terminus altitude rising from 2790 to $2950 \mathrm{~m}$; while from 2000 to 2011, it shows a $358 \mathrm{~m}$ retreat with an annual retreat rate of $29.8 \mathrm{~m} / \mathrm{a}$ and the terminus altitude rising from 2950 to $2980 \mathrm{~m}$.

Glacier Qingbingtan No. $72\left(79^{\circ} 5263^{\prime} \sim 79^{\circ} 5467^{\prime} \mathrm{E}\right.$, $41^{\circ} 4495^{\prime} \sim 41^{\circ} 4798^{\prime} \mathrm{N}$; glacier number is $5 \mathrm{Y} 673 \mathrm{P} 0072$ ) is a compound valley glacier, located at Kumalike

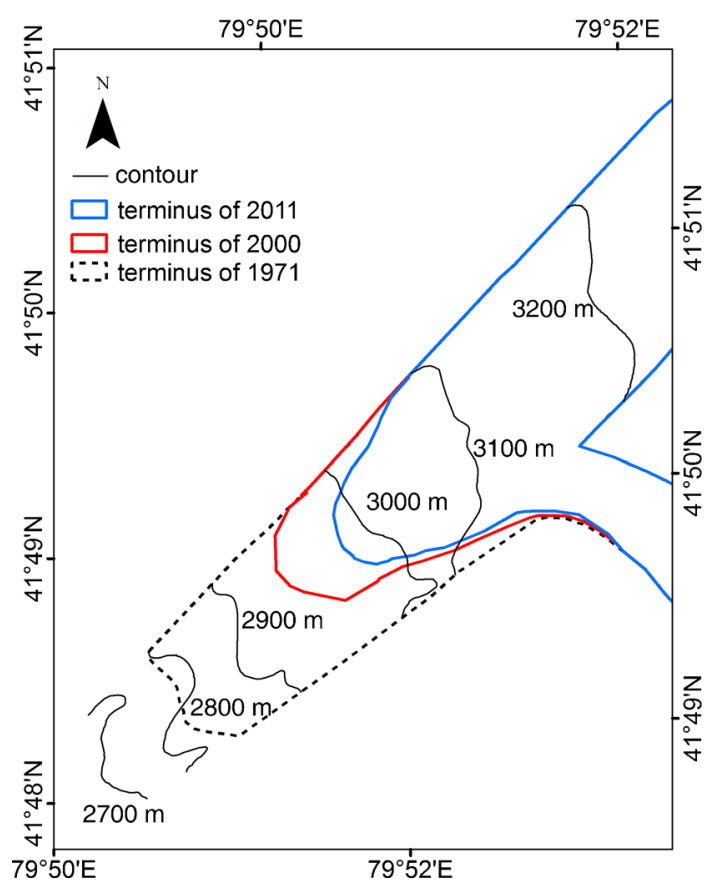

Figure 7. Terminus change of the Tomur glacier. 
River Basin. The elevation from the glacier terminus to the highest point ranges from 3720 to $5980 \mathrm{~m}$, and its area is $5.87 \mathrm{~km}^{2}$, and the glacier length is $4.7 \mathrm{~km}$. We found that this glacier area has an increase from 1964/71 to 2000, and the glacier has retreated at a rate of $24.6 \mathrm{~m} / \mathrm{a}$ since 2000. To investigate reasons why this glacier area has an increase, we speculate that errors in the original topographic maps might be the possible cause, and besides that, the snow and cloud covers in the Landsat $\mathrm{ETM}^{+}$could affect the results. Glacier Qingbingtan No. $74\left(79^{\circ} 54.05^{\prime} \sim\right.$ $79^{\circ} 56.28^{\prime} \mathrm{E}, 41^{\circ} 44.48^{\prime} \sim 41^{\circ} 48.13^{\prime} \mathrm{N}$; glacier number is 5Y673P0074) is close to Glacier Qingbingtan No. 72. This glacier showed an area reduction rate of $0.59 \%$ /a from 1964 to 2000, and 0.64\%/a from 2000 to 2011. Similar to these glacier changes, glacier 5Y673P0077 and 5Y673P0096 also showed same change.

As it can be seen from table 1 , the rate of area loss for the Tomur glacier (5Y673P0037) was significantly lower than other glaciers, and the area changing trend of the Tomur glacier is opposite of other small glaciers like 5Y673P0072, 5Y673P0074, 5Y673P0077, and 5Y673P0096 (we define glaciers with an area $<1 \mathrm{~km}^{2}$ as small glaciers according to the CGI). The absolute area loss varied from $-36.26 \%$ (5Y673P0077) to $7.72 \%$ (5Y673P0072) for 1964/71-2000 period, while the total loss was the highest for the 5Y673P0077 glacier and the lowest for the Tomur glacier. Taking into account the influence of the glacier size, we found a nonlinear relationship between glacier initial size and percentages of area loss in the Tomur Peak region. Figure 8 shows that, most of the small glaciers in the Tomur of the Peak region have a high glacier area loss between 1964/71 and 2011. For the studied glaciers, variability in the percent area lost by small glaciers is high, ranging from $20 \%$ to $100 \%$,

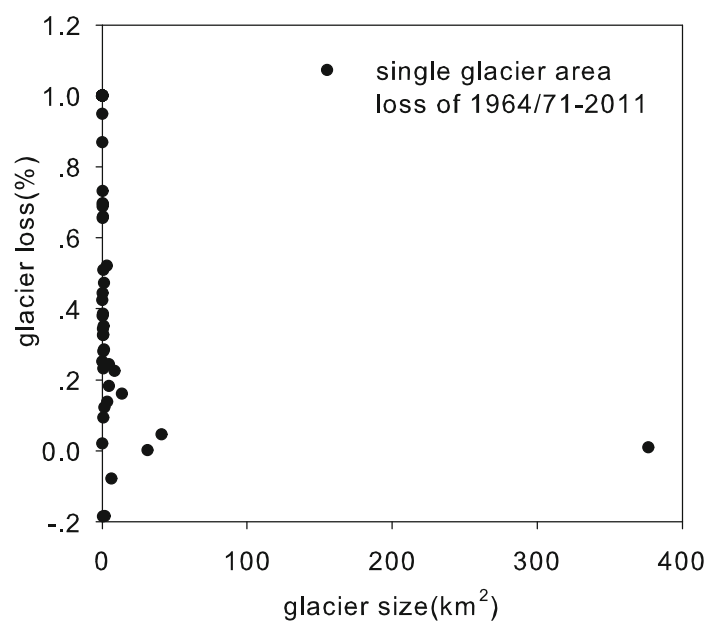

Figure 8. Single glacier area loss of different size in the Tomur Peak region from 1964/71 to 2011. and large glaciers (we define glaciers with an area $>10 \mathrm{~km}^{2}$ as large glaciers according to the CGI) is small. As for the relative glacier changes as a function of glacier size, the area reduction of small glaciers were usually higher than those of large glaciers. This indicates that the small glaciers were more sensitive to climate change than large glaciers.

\subsection{Glacier thickness change estimates}

The spatial variation of the thickness change of the Tomur Peak glaciers is shown in figure 9. The mean thickness change for the investigated period (1964/71-2000) revealed a significant ice loss, and the average glacier thinning is $22.35 \mathrm{~m}$ with a maximum thinning of $62.40 \mathrm{~m}$ and a maximum accumulation of $32.70 \mathrm{~m}$, indicating an average thinning of $0.60 \mathrm{~m} / \mathrm{a}$ (most topographic maps are acquired in 1964). The surface elevation for about $73.51 \%$ of grid area decreased, mostly in the glacier ablation zone. The strongest elevation losses are found at around $2800 \mathrm{~m}$, at the terminus of the glacier outlets. A belt above the snow line of the glacier is frequently found to be an accumulative zone, even though a slight elevation increases at the ridge area. The largest elevation loss (up to $42.40 \mathrm{~m}$ ) occurs at the glacier tongue, which shows very obvious thinning. Besides, this work shows that the Tomur glacier is thinning as a whole state. The thickness change at the mainstream line of the Tomur glacier is generally bigger than the east and west sides, and similarities can be found in other glaciers with same aspects (Wang et al. 2013; Xu et al. 2013).

\subsection{Glacier volume loss estimates}

The difference between the corrected DEM maps contains information about each pixel elevation change, and with glacier area change estimated from the boundary difference, the glacier volume loss can be calculated using the arithmetic mean of the glacier elevation differences multiplying the total glacier area in 1964/71. Then, the ice volume loss during the study period can be further derived. The results show that the Tomur Peak glaciers ice volume loss is up to $16.68 \mathrm{~km}^{3}$ in the $1964 / 71-2000$ period for an equivalent water volume of $15.01 \mathrm{~km}^{3}$ (ice density is $0.9 \mathrm{~g} / \mathrm{cm}^{3}$ ).

According to previous study (Liu et al. 2003; Xu et al. 2013), the empirical relation between glacier area and volume was founded by Liu et al. (2006) for glaciers in western China, which is expressed as follows:

$$
V=0.04 \times S^{1.35}
$$

where $S$ is the glacier area $\left(\mathrm{km}^{2}\right)$ and $V$ is the glacier volume $\left(\mathrm{km}^{3}\right)$. The formula was induced 


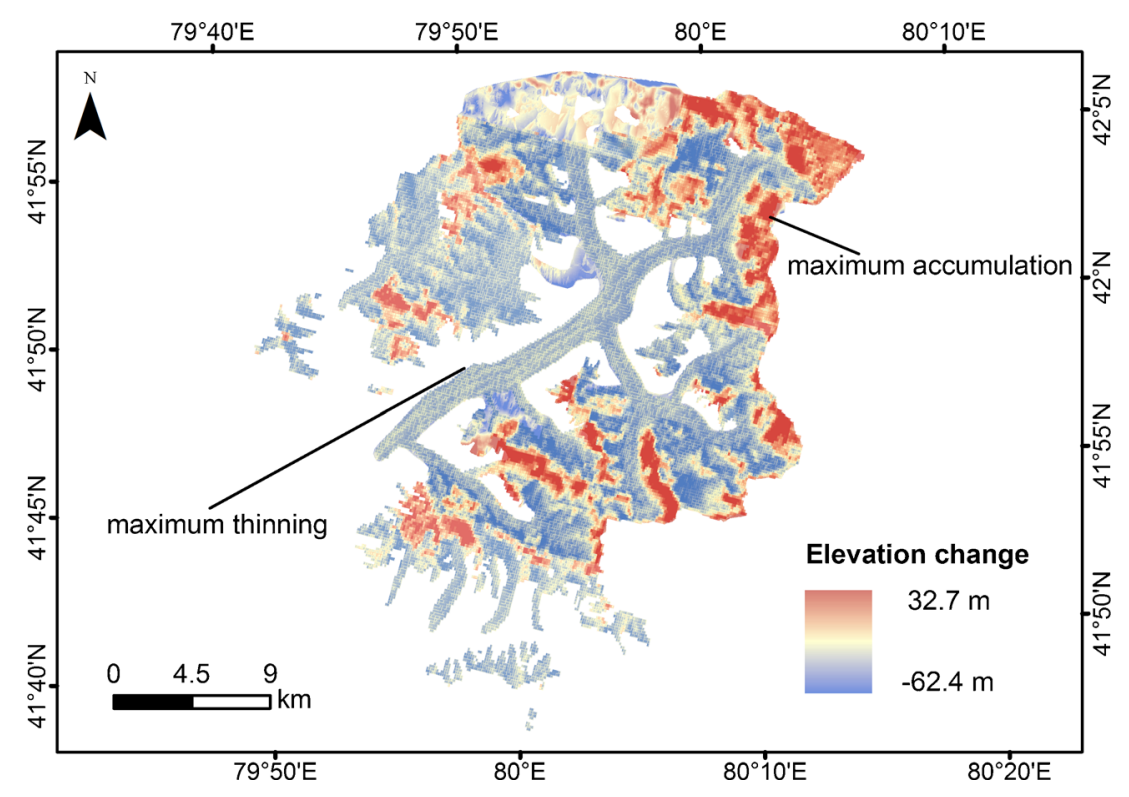

Figure 9. The spatial pattern of the thickness change of 78 glaciers in the Tomur Peak region from 1964/71 to 2000.

based on a statistical model and it is used to estimate the glacier volume change for a large region of glaciers instead of for individual glaciers. Due to the lack of DEM in 2011, this statistical formula was applied to estimate glacier volume change for the 2000-2011 period in the Tomur Peak region. The glacier surface area loss was about $8.5 \mathrm{~km}^{2}$ during the period, so the ice volume reduction was estimated as $0.72 \mathrm{~km}^{3}$. Compared with the results of using the thickness spatial distributionarea change method mentioned above for 1964/71$2000\left(16.68 \mathrm{~km}^{3}\right.$, an average volume loss about $0.45 \mathrm{~km}^{3} / \mathrm{a}$ ), the statistical formula method as used for the $2000-2011$ period $\left(0.72 \mathrm{~km}^{3}\right.$, an average volume loss of $0.06 \mathrm{~km}^{3} / \mathrm{a}$ ) probably underestimated the glacier volume loss, regarding the above findings of the accelerated area reduction during 2000-2011.

\subsection{Discussion}

\subsubsection{Comparison with glacier recessions in other regions}

We compared the glacier change in the Tomur Peak region with the studies in other mountain ranges in western China (table 2). As for the glacier recession rate of other mountains in western China, such as Tien Shan Mountains (Wang et al. 2011) (0.22\%/a), A'nyêmaqên Mountains (Liu et al. 2002) $(0.49 \% / a)$, Geladandong Mountains (Lu et al. 2002) (0.05\%/a), Naimona Nyi Mountains (Ye et al. 2007) $(0.26 \% / \mathrm{a})$, the Tomur Peak showed a lower retreat speed $(0.13 \% / \mathrm{a})$. The regional climate change (temperature and precipitation) might be the main reason behind this relative reduction in glacier area at the Tomur Peak while the glacier size is also a factor (Jóhannesson et al. 1989). Also, there is no doubt that the heavy debris cover slows down the retreating trend by decreasing the ablation efficiency (Karimi et al. 2011).

\subsubsection{Effects of climate change on glacier changes}

Precipitation and temperature and their interannual change are the main climatic factors affecting glacier development and determine glacier's nature, development, and evolution (Xie and Liu 2010). Temperature affects the melting while precipitation affects the accumulation (Li et al. 2003). In figure 10, the rate of temperature increase at all four stations was larger than $0.20^{\circ} \mathrm{C} / 10 \mathrm{a}$ (statistically significant at the 0.01 level). The trend magnitudes were all higher than the global average increase rate $\left(0.15^{\circ} \mathrm{C} / 10 \mathrm{a}\right)$ (IPCC 2007). Similar to temperature change, the total precipitation at each station also rose slightly throughout the study period. The rate of total annual precipitation increasing was higher than $5 \mathrm{~mm} / 10$ a for all four stations. According to Kang (1996), the glacier Equilibrium Line Altitude (ELA) increased by $100-160 \mathrm{~m}$ if the summer temperature rose by $1^{\circ} \mathrm{C}$ as seen for 12 glaciers in the High Asia. In order to compensate this effect and keep the ELA unchanged, the precipitation would have to be increased by $40 \%$ or double the amount of the solid precipitation (Kang 1996). Therefore, with such regional climate changes in recent decades, the gradual upward shifting of glacier terminus is also a consequence of upward shifting in ELA, indicating glacier retreats in the Tomur Peak region as a consequence of regional climate change. 
Table 2. Glacier recession in other mountains of the western China.

\begin{tabular}{|c|c|c|c|c|c|c|}
\hline Study area & $\begin{array}{l}\text { Area } \\
\text { change } \\
\left(\mathrm{km}^{2}\right)\end{array}$ & $\begin{array}{c}\text { Relative } \\
\text { change (\%) }\end{array}$ & Recession & Data source & Period & Reference \\
\hline Western Qilian Mountains & -124.20 & -10.30 & -0.29 & Aerial photo, ETM & 1956-1990 & Liu et al. (2002) \\
\hline Chinese Tien Shan Mountains & - & -11.50 & -0.22 & - & $1960-2010$ & Wang et al. (2011) \\
\hline A'nyêmaqên Mountains & -21.70 & -17.00 & -0.49 & TM & $1966-2000$ & Liu et al. (2002) \\
\hline Geladandong Mountains & -14.91 & -1.70 & -0.05 & Aerial photo, TM & 1969-2000 & Lu et al. (2002) \\
\hline Naimona Nyi Mountains & -7.12 & -8.44 & -0.26 & MSS,TM, ASTER & $1976-2003$ & Ye et al. (2007) \\
\hline Mt. Qomolangma & -501.91 & -15.63 & -0.52 & MSS, TM & $1976-2006$ & Nie et al. (2010) \\
\hline Tomur Peak region & -33.56 & -6.04 & -0.13 & $\begin{array}{l}\text { Topographic maps, } \\
\mathrm{ETM}^{+}\end{array}$ & $1964 / 71-2011$ & This study \\
\hline
\end{tabular}
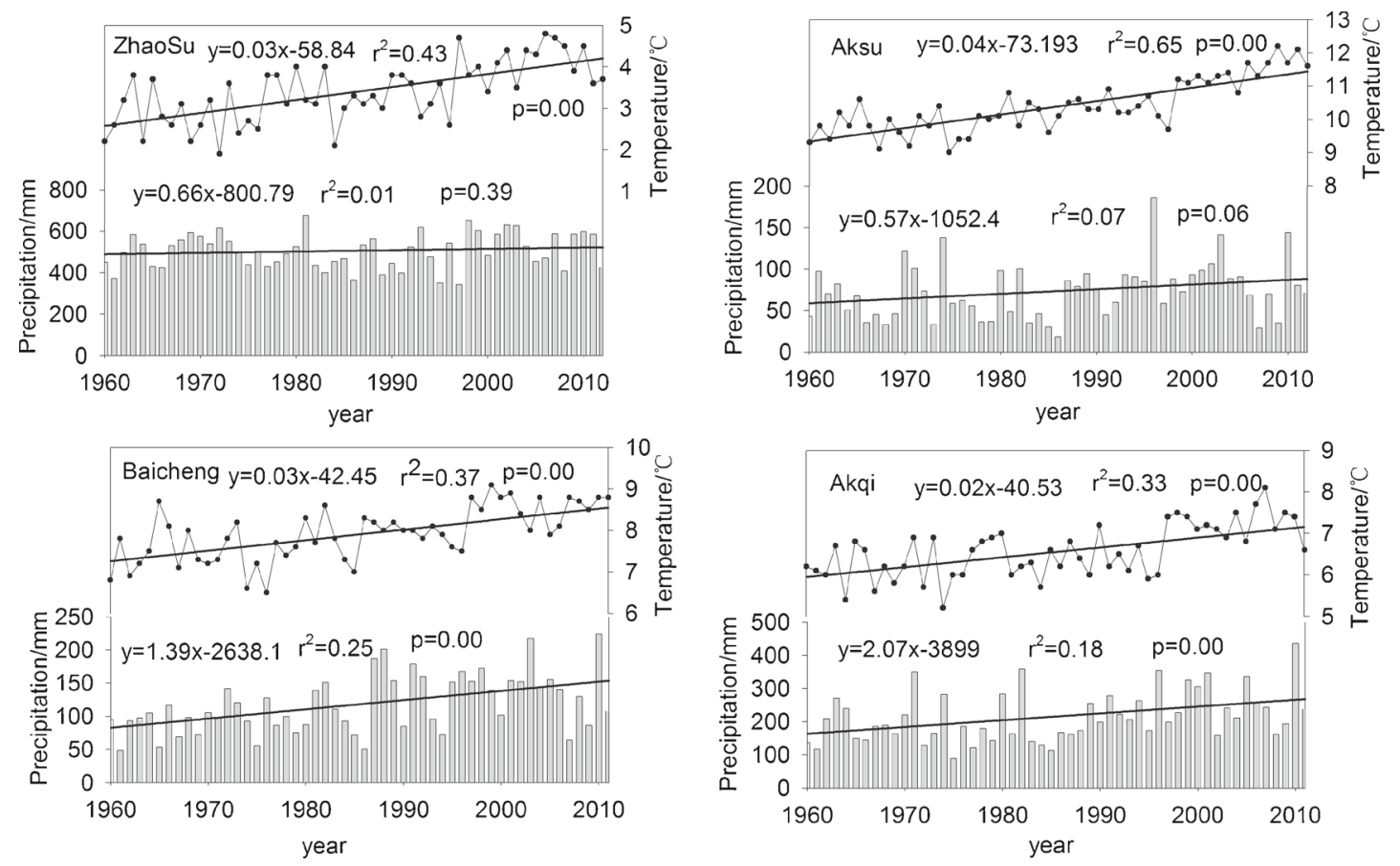

Figure 10. Annual mean temperature and total precipitation trends during 1960-2011 at four meteorological stations around the Tomur Peak region.

\section{Conclusions}

In this paper, we studied glacier area and thickness change of the Tomur Peak region. Following conclusions can be drawn:

- According to the statistics of glacier vector data, the number of selected glaciers in the Tomur Peak region decreased from 78 in 1964/71 to 64 in 2000, and to 61 in 2011. The total area of the selected 78 glaciers was reduced from 555.45 $\mathrm{km}^{2}$ in $1964 / 71$ down to $530.39 \mathrm{~km}^{2}$ in 2000 and to $521.89 \mathrm{~km}^{2}$ by 2011 . Overall, the selected glaciers have lost $4.51 \%$ of their surface area from $1964 / 71$ to 2000 , and have lost $1.60 \%$ from 2000 to 2011. Apparently, the retreat of glacier has been accelerated, with the rate of area reduction increased from $0.12 \% /$ a to $0.13 \%$ /a of the two periods.

- About $73.51 \%$ glacier surface in DEM grids has elevation decrease for the targeted 78 glaciers, mostly occurring in the glacier ablation zone. The glaciers have experienced an average thinning of $22.35 \mathrm{~m}$ with a maximum thinning of $62.40 \mathrm{~m}$ and a maximum accumulation of 32.70 $\mathrm{m}$, suggesting a thinning rate of $0.6 \mathrm{~m} / \mathrm{a}$.

- The data from four meteorological stations reveal that the annual rate of temperature increase was larger than $0.20^{\circ} \mathrm{C} / 10$ a for the $1960-2011$ period in the Tomur Peak region. An increase in precipitation is also seen, with the average rate higher than $5 \mathrm{~mm} / 10 \mathrm{a}$. Within the regional climate change context, the gradual upward shifting of glacier terminus is also a consequence of a shift in 
ELA which has been constantly moving upwards showing a retreat of the glaciers of the Tomur Peak.

\section{Acknowledgements}

This work was supported by the funds for the Creative Research Groups of China (41121001), Project for Incubation of Specialists in Glaciology and Geocryology of National Natural Science Foundation of China (J1210003/J0109), National Natural Science Foundation of China (41340014), and National Basic Research Program of China (2013CBA01801). The authors are very grateful to USGS (US Geological Survey, http://www.usgs. gov) for the Landsat image data and China Meteorological Data Sharing Service System for meteorological data. They also greatly acknowledge Mathias Bavay for help with English polishing on the manuscript.

\section{References}

Aðalgeirsdóttir G, Echelmeyer K and Harrison W 1998 Elevation and volume changes on the Harding Icefield, Alaska; J. Glaciol. 44(148) 570-582.

Arzhan B S and Aizen V B 2006 Estimating volume change of mountain glaciers using SRTM and map-based topographic data; IEEE Trans. Geosci. Remote Sens. 44(10) 2991-2995.

Baltsavias E, Favey E, Bauder A, Boesch H and Pateraki M 2001 Digital surface modelling by airborne laser scanning and digital photogrammetry for glacier monitoring; J. Photogramm. 17(98) 243-273.

Bayer K J, Hall D K and Kovalick W M 1994 Observations on glaciers in the eastern Austrain Alps using satellite data; Int. J. Remote Sens. 15(9) 1733-1742.

Berthier E and Toutin T 2008 SPOT5-HRS digital elevation models and the monitoring of glacier elevation changes in north-west Canada and south-east Alaska; Rem. Sens. Environ. 112 2443-2454.

Berthier Y, Arnaud D, Baratoux C and Vincent F 2004 Recent rapid thinning of the 'Merde' glacier derived from satellite optical images; Geophys. Res. Lett. 31 1-4.

Bishop M P 2004 Global land ice measurements from space (GLIMS): Remote sensing and GIS investigations of the Earth's Cryosphere; Geocarto. Int. 19(2) 57-84.

Bolch T 2007 Climate change and glacier retreat in northern Tien Shan (Kazakhstan/Kyrgyzstan) using remote sensing data; Global Planet. Change 56(1-2) 1-12.

Finsterwalder R 1954 Photogrammetry and glacier research with special reference to glacier retreat in the eastern Alps; J. Glaciol. 2 306-315.

Frezzotti M, Capra A and Vittuari L 1998 Comparison between glacier ice velocities inferred from GPS and sequential satellite images; Ann. Glaciol. 27 54-60.

Guo H R, Jiao W H and Yang Y X 2004 The systematic difference and its distribution between the 1985 national datum and the global quasigeoid; Acta. Geodaetica e 33(2) 100-104.

Hall D K, Bayer K and Schfner W 2003 Consideration of the errors inherent in mapping historical glacier positions in Austria from ground and space 1893-2001; Rem. Sens. Environ. 86 566-577.

Houghton J T 2001 Climate change: The scientific basis; Contribution of Working Group I to the Third Assessment Report of the Intergovernmental Panel on Climate Change (Cambridge: Cambridge University Press), pp. 22-79.

IPCC 2007 The Fourth Assessment Report of the Intergovernmental Panel on the Climate Change (Cambridge: Cambridge University Press), pp. 1-996.

Jacobs J D, Simms E L and Simms A 1997 Recession of the southern part of Barnes Ice Cap, Baffin Island, Canada, between 1961 and 1993, determined from digital mapping of Landsat TM; J. Glaciol. 43(143) 98-102.

Jóhannesson T, Raymond C and Waddington E 1989 Timescale for adjustment of glaciers to changes in mass balance; J. Glaciol. 35 355-369.

Josberger E G, Campbell W J, Gloersen P, Chang A T C and Rango A 1993 Snow conditions and hydrology of the upper Colorado River Basin from satellite passive microwave observations; Ann. Glaciol. 17 322-326.

Kaab A, Huggel C, Paul F, Wessels R, Raup B and Kieffer H 2003 Glacier monitoring from ASTER imagery: Accuracy and applications; EARSel eProceedings 2 $43-53$.

Kang E S 1996 Energy balance characteristics and mass balance change calculation research of Cryosphere in High Asia; J. Glaciol.Geocryol. 18(Suppl.) 12-22.

Karimi N, Farokhnia A, Karimi L, Eftekhari M and Ghalkhani H 2011 Combining optical and thermal remote sensing data for mapping debris-covered glaciers (Alamkouh Glaciers, Iran); Cold. Reg. Sci. Technol. 71 73-83.

Krishna A P 1996 Satellite remote sensing applications for snow cover characterization in the morphogenetic regions of upper Tista river basin, Sikkim Himalaya; Int. J. Remote Sens. 17 651-656.

Li Y N and Li Y K 2014 Topographic and geometric controls on glacier changes in the central Tien Shan, China, since the Little Ice Age; Ann. Glaciol. 55(66) 177-185.

Li Z Q, Han T D and Jing Z F 2003 A summary of 40-year observed variation facts of climate and glacier No. 1 at headwater of Urumqi River, Tien Shan, China; J. Glaciol. Geocryol. 25(2) 117-123.

Liu S Y, Ding Y J and Zhang Y 2006 Impact of glacier change on water resources in the Tarim River Basin; Acta Geogr. Sini. 61(5) 482-490.

Liu S Y, Lu A X and Ding Y J 2002 Glacier fluctuations and the inferred climate changes in the Anyêmaqên Mountains in the source area of the Yellow River; J. Glaciol. Geocryol. 24(6) 701-707.

Liu S Y, Sun W X, Shen Y P and Li G 2003 Glacier changes since the Little Ice Age maximum in the western Qilian Shan, northwest China, and consequences of glacier runoff for water supply; J. Glaciol. 49 117-124.

Lu A, Yao T and Liu S 2002 Glacier change in the Geladandong area of the Tibetan Plateau monitored by remote sensing; J. Glaciol. Geocryol. 24(5) 559-562.

Muskett R R, Lingle C S, Tangborn W V and Rabus B T 2003 Multidecadal elevation changes on Bagley Ice Valley and Malaspina Glacier, Alaska; Geophys. Res. Lett. 30(16) 1857.

Narama C, Kääb A, Duishonakunov M and Abdrakhmatov K 2010 Spatial variability of recent glacier area changes in the Tien Shan Mountains, central Asia, using Corona $(\sim 1970)$, Landsat $(\sim 2000)$, and ALOS $(\sim 2007)$ satellite data; Global Planet. Change 71 42-54.

Nie Y, Zhang Y L, Liu L S and Zhang J P 2010 Monitoring glacier change based on remote sensing in the Mt. 
Qomolangma National Nature Preserve, 1976-2006; Acta. Geogr. Sin. 65(1) 13-28.

Paul F, Kaab A, Maisch M, Kellenberger $\mathrm{T}$ and Haeberli W 2004 Rapid disintegration of Alpine glaciers observed with satellite data; Geophys. Res. Lett. 31 L21402.

Rabus B, Eineder M, Roth A and Bamler R 2003 The Shuttle Radar Topography Mission - A new class of digital elevation models acquired by spaceborne radar; J. Photogramm. 57(4) 241-262.

San B T and Suzen M L 2005 Digital elevation model (DEM) generation and accuracy assessment from ASTER stereo data; Int. J. Remote Sens. 26(22) 5013-5027.

Sapiano J, Harrison W and Echelmeyer K 1998 Elevation, volume and terminus changes of nine glaciers in North America; J. Glaciol. 44(146) 119-135.

Shi Y F 2005 Concise Chinese Glacier Inventory (Shanghai: Shanghai Scientific Popularization Press), pp. 17-188.

Silverio W and Jaquet J M 2005 Glacial cover mapping (1987-1996) of the Cordillera Blanca (Peru) using satellite imagery; Rem. Sens. Environ. 95(3) 342-350.

Smith B E, Bentley C R and Raymond C F 2005 Recent elevation changes on the ice streams and ridges of the Ross Embayment from ICESat crossovers; Geophys. Res. Lett. 32 L21S09.

State Bureau of Surveying and Mapping 2007 Technical rules for producing digital products of 1:10000 1:50000 fundamental geographic information; State Bureau of Surveying and Mapping, Beijing.

Wang J and Lu C 2003 Problem of coordinate transformation between WGS 84 and Beijing 54; J. Geodesy. Geodyn. 23(3) 70-73.

Wang Y T, Chen X W, Bo Y C and Li X L 2010 Monitoring glacier volume change based on multi-source DEM and multi-temporal remote sensing images - a case study in the Mount Naimonanyi region on the Tibetan Platea; J. Glaciol. Geocryol. 32(1) 126-132.

Wang S J, Zhang M J and Li Z Q 2011 Glacier area variation and climate change in the Chinese Tien Shan Mountains since 1960; Acta. Geogr. Sin. 21(2) 263-273.

Wang P Y, Li Z Q, Wang W B, Li H L, Zhou P and Jin S 2013 Changes of six selected glaciers in the Tomor region, Tien Shan, central Asia, over the past 50 years, using high-resolution remote sensing images and field surveying; Quat. Int. 311 123-131.

Xie Z C and Liu C H 2010 Introduction of Glaciology (Shanghai: Shanghai Kexuepuji Press), 425p.

$\mathrm{Xu} \mathrm{J} \mathrm{L,} \mathrm{Liu} \mathrm{S} \mathrm{Y,} \mathrm{Zhang} \mathrm{S} \mathrm{Q,} \mathrm{Guo} \mathrm{W} \mathrm{Q} \mathrm{and} \mathrm{Wang} \mathrm{J}$ 2013 Recent changes in glacial area and volume on Tuanjiefeng Peak region of Qilian Mountains, China; PLOS ONE 8(8) e70574.

Ye Q H, Chen F and Yao T D 2007 Tupu of glacier variations in the Mt. Naimona Nyi region, western Himalayas in the last three decades; J. Remote Sens. 11(4) 511-520. 